\title{
Black Economic Empowerment in South Africa: Challenges and Prospects
}

\author{
Elvin Shava \\ North West University, South Africa \\ ellyshava@gmail.com
}

\begin{abstract}
The purpose of this paper is to assess if the Black Economic Empowerment act has brought new economic horizons for the historically disadvantaged South Africans, or it has contributed to further impoverishmentof the lower classes in communities. The paper based its argument on an extensive literature review which envisaged that, despite many years of its implementation, BEE has caused the emergence of classes resulting fromfraud and corruption, fronting, difficulties in registering status, political interference, and poor accountability strategies. The paper interrogates the implementation strategies of BEE in the local government context to assess whether historical imbalances have been addressed or not. The paper concludes that the government needs to revisit BEE as an economic empowerment policy to see whether it has benefited the black majority or not. The paper reiterates further that, BEE as a black economic emancipation blueprint requires proper implementation and alignment with other economic policies such as the National Development Plan to accelerate economic opportunities for the black majority. The paper recommends the government of South Africa through local municipalities to exercise monitoring and evaluation in the BEE procurement systems are prerequisites in safeguarding the manipulation and corrupt tendencies arising from the awarding of tenders in the local government.
\end{abstract}

Key words: Black Economic Empowerment, South Africa, Challenges, Prospects

\section{Introduction}

In South Africa, the Black Economic Empowerment policy (BEE) has been implemented as an entrepreneurial way of redressing the socio-economic ills perpetrated by the former apartheid government. According to Barlett (2010) BEE is aimed at empowering the majority of South African black people who were previously suppressed by the apartheid government in participating in the economic affairs of the state. BEE seeks to reallocate wealth across a broader continuum of society in South Africa to influence change in all sectors of life. Burger (2010) reiterates that BEE is aimed at transforming the economy to be fully representative of the demographic make-up of the country. To this end therefore; BEE provides a meaningful contribution to the economic lives of black people, in the process ensuring economic growth and transformation races. Based on the above assertions, BEE initiatives aim to reinvigorate South African economic landscape through equitable share of wealth and ensuring public participation of South African citizens (Kalula and M'Paradzi, 2008). The Constitution of South Africa (1996) condemns all acts of gross economic disempowerment of non-white individuals during apartheid era, and gave a leeway to the implementation of BEE in local government which is a fundamental and entrepreneurial strategy towards controlling and redistributing the resources of the country equitably across all races (Kalula and M'Paradzi, 2008).

Current debate on BEE in South African local government is centred on the manipulation and abuse of the procurements systems by powerful officials who inhibit theblack majority to benefit. Papenfus (2015) acknowledges the past injustices perpetrated by apartheid regime in South Africa; however, the question still remains on the way forward in equitably restoring wealth to previously marginalised black people. Jeffery (2016) reiterates that, BEE in South Africa has failed to ignite the much needed black economic transformation which made the public to lose confidence in the African National Congress (ANC) economic policy. Jeffery (2016) argues that, in the local context BEE has been flawed as a result of scarce capital, lack of skills, high level bureaucracy and inexperienced entrepreneurial minds. Pravid Gordhan the finance minister in 2010 endorses that "BEE policies have not worked and have not made South Africa a fairer or more prosperous country."Lawrence Mavundla as cited in Jefferey (2016), who was the president of the National African Federated Chamber of Commerce and Industry, lambasted BEE and its procurement systems as it had impoverished emerging entrepreneurs and small businesses instead of assisting them Moletsi Mbeki (2016) condemned BEE as it has promoted 'tenderpreneurs' or thieves who acquire tender through politically motivated influence. Based on these assertions the paper seeks to question the effectiveness of BEE in redressing the imbalances of the past. The paper examines the policy of BEE to see if it has led to the transfer 
of wealth tomajority of black South Africans. The paper interrogates the prevalence of corruption and fraud in the BEE procurement systems and assesses how it can be curbed to enhance community empowerment.

\section{Literature Review}

Broad Based Black Economic Empowerment B-BBEE in the South African Context: BEE in South was the brainchild of the B.BBEE which has since been amended to BEE in 2014 to serve a more integrated purpose as a government strategy of redressing the imbalances of the past. Davies (2014) termed "BEE an economic imperative' in the Government Gazette of 27Jan 2014 leading to the signing of the act by the President to be used in the public sector. Various groups are recognised under the Act such as workers, women, youth people with disabilities and rural residents. These groups which encompass, Africans, Coloureds and Indians are empowered in an integral and diverse manner which targets their socio-economic well-being. The purpose is to empower several blackpeople sothat they own and management of own businesses, facilitate ownership and management of business and productive assets of community members. The policy aims to promotecooperative development human resource and skills development, provide equal opportunity to blacks to be employed in jobs and practising preferential procurement of black owned enterprises (DTI, 2014).

Positioning Black Economic Empowerment (BEE) in South African local government: There is no universally accepted meaning of BEE in South Africa, since it depends on which context the scholar wants to use it and for what purpose. The emergence of Local Economic Development confuses scholars who often equate it to BEE although the two aim to economically empower local people they differ in principle and practice (Boshoff, 2012). According to Brown and Gqubule (2001:1) BEE has been narrowly equated to the development of a capitalist class focusing on enriching black landlords in the business world. Maphanga (2005:5-6) asserts that BEE is an integrated and coherent socio-economic approach that is geared towards redressing the imbalances of the past. Kalula and M'Paradzi (2008) therefore; regard BEE as an initiative designed to empower the historically disadvantaged individuals to improve their living standards. Barlett (2010) reiterates that in South Africa, BEE should be regarded as an economic empowerment programme implemented in response to debates or criticism concerning the narrow based empowerment implemented in 2003/4. The authors' argument is premised on the idea that, the narrow based empowerment measures only equity ownership and management representation. In South Africa, as Burger (2010) observes BEE has been used as an economic empowerment policy meant to economically empower black people (workers, women, men, disabled persons and rural citizens). The policy is meant to increase control ownership and management of properties by black people in an equitable and sustainable manner in all sectors of employment and governments. This was enabled through preferential procurement policies. DTI (2004:4-5) contends further that, in South African municipalities, BEE should be treated as a legislative created to economically empower black South Africans through local economic development initiatives to improve on their standards of living,

\section{Theoretical perspectives on Black Economic Empowerment}

Organisational Theory: Andrews(2008) observes that, BEE in South Africa should be implemented based on the organisational theory which entails various intra and inter-firm relational structures which established networks that influence citizens to participate in the economic well-being activities. Based on this argument BEE in South Africa should restructure socio-economic statuses of the previously disadvantaged people despite their racial backgrounds. The organisational theory assumes relevant structures which can be used by municipalities to create opportunities not only in the procurement systems but in local economic development initiatives which can uplift the lives of poor black people. Lindsay (2015) argues that, in South Africa, BEE can be used as a catalyst in accelerating economic growth among poor communities. Critical scholarship argues that organisational structural arrangements can constrain the economic actors since they determine which should be involved and when in the main stream economy. Such a condition can exclude the previously marginalised groups since municipalities due to corruption and nepotism can fail to empower such groups to improve their living standards in the process defeating government efforts to restore wealth to historically marginalised black population. 
Theory of Social Justice: To position BEE as an economic mechanism for correcting past social-economic injustices, the theory of social justice contains provisions which draw points of analysis on how the government can implement the framework to empower its previously disadvantaged population (Poe, 2013). The theory social and distributive justice has its own merits though it creates some controversies. Various black marginased groups believe the economic landscape should be shifted in their favour hence vast mobilisations and advocacy has been seen in South African communities among blacks versus blacks or white against blacks. Such tensions have resulted in critics questioning BEE whether is it indeed meant for economic empowerment or conflict breeding mechanism (Stewart, 2001; Easterly, 2002). Social justice in South Africa has been enshrined in the Constitution where social justice and improved quality of life are key priorities (RSA, 2001). Black Economic Empowerment is therefore; meant to restore past injustices by rewarding black entrepreneurs with equal opportunity to obtain big business and government contracts to improve their living standards. Fair equality as Bringhouse (2002:183) observes provides opportunities and equal working conditions to exercise social justice. Gerwitz \& Gribb (2002:499) reiterate that, social justice in BEE means equal opportunities for the marginalised groups and redistributing of economic means to those groups as way of improving their livelihoods both socially and economically. Steger (2009:113) remarks that, the state should play a pivotal role in addressing social injustices which is the sole mandate of BEE especially in municipal procurement systems. As Rawls (2007:571) puts it, social justice spells a situation where there is social and economic equality among all races despite race or religious and cultural background.

Features of Black Economic Empowerment and the Generic Scorecard: The implementation of BEE in South African organisations is grounded in several evaluation principles embedded in their BEE compliance. These have been discussed below:

Ownership: DTI (2006:8) the right of ownership is contained in the Code of Good Practice enterprise BEE compliance measured through the generic scorecard. Under this assumption, broad-based ownership is imaginative and pension funds and investments schemes are excluded on the equity system (DTI, 2006).

Control: In terms of BEE, the code gives an element of managerial oversight and assesses managerial efficiency of black leaders in enterprises (DTI, 2006:9).

Employment equity: BEE policy in South is geared towards employment equity where previously marginalised groups can obtain an equal chance to get jobs. The codes stipulate equity and measurements on how BEE firms should employ people (DTI, 2006:9). BEE companies are required to be non-sexist and nonracial and provide good working environments to enhance sustainability and diversity of cultures (Mathura, 2009:47).

Employment equity Act: DTI (2014:30) explains that, this entails a set of rules and regulations that need to be taken into consideration by companies, and it is essential for developing public participation by all races in participating companies

Procurement: DTI (2006:10) affirms that, the codes stress out the elements of Preferential Procurement that shows the manner in which a business closely trade with other BEE firms complying with BEE suppliers and owner of black businesses. Mathura (2009:46) endorses that compliance on the side of suppliers is conducted by reviewing the terms of sectorial charter of the code as well as generic scorecard. Certain amount of points is awarded to a company to evaluate its B-BBEE status based on Weighting Recognition of an enterprise.

Skills development: According to (DTI 2006:9) black people need to be trained on how they can improve on their skills both to be employable in public and private sector. The abundance of low skilled personnel and high skilled labour force does not match the investment of skills in the laborers. To solve such crisis, BEE demands evaluated companies to instil mentorship programmes within their companies. Mathura (2009:47) states that companies need to provide proof of the submission and implementation of these programmes in their companies and this must be portrayed in their annual BBBEE reports. Failure to comply in this category renders a zero score. 
Enterprise development: Mathura (2009:48) states that the collaboration and joint venture of emerging entrepreneurs and small businesses is encouraged for enterprise development. Fostering partnership is important for reallocating wealth to black communities through sharing skills and investment techniques. Black owned firms and established firms can enter into mutually beneficial partnerships which may require outsourcing of labour to execute huge programmes (DTI, 2014:31)

Human resource development: The effective implementation of BEE depends on the availability of competent skills and equity employment which have roots in human resource development. These contain 30 points which contribute equally (Burger \& Jafta, 2010:10).In line with skills development, expenditure is measured as a percentage of the total payroll. Expenditure should be aligned with Skills Development Act 97 of 1998 and Skills Development Levies Act 9 of 1999.

Direct empowerment: Mason and Watkins (2005:2) state that management control and ownership determines direct empowerment and amounts to 30 points on the scorecard. The process of BEE stipulates that; ownership should be transferred to black people as way of increasing control on the mainstream economy. This can only happen in event black people acquire properties and businesses in the economy of the country. Usually the transfer of wealth is associated with risks and actual participation in making decisions at operational and managerial level. The DTI (2014:30) reasons that, the management regulates votes, appointments and removal of management shareholders and directors.

Indirect empowerment: Burger \& Jafta (2010:10) explain that in procurement systems, indirect empowerment account for 20 points, corporate social investment 5 points, enterprise development 15 points equalling 40 points. New comers can be helped by preferential procurement to increase their opportunity and output. The extent at which the principles of BEE have been achieved remains debatable in local government in South Africa. Analysts (Mbeki, 2009; Kovacevic, 2007) argue that, BEE has led to 'tenderpreneurship' where individual black people have amassed enormous wealth at the expense of the poor through corruption tendencies particularly in various municipal procurement systems. Several black communities in South Africa still suffer economically and are living on government grants although BEE was meant to restore black identity in terms of economic well-being. Beyers \& Koorbanally (2010:3) \& Centre for Development \& Enterprise (2010:44) mourn the abuse of BEE in their argument, they assert that 'tenderpreneurs' have accumulated huge amounts of wealth through unethical and unjustifiable methods under the mask of affirmative action. Bezuidenhout et al. (2009:212) reiterates that, the rampant corruption in local government in South Africa has enriched unscrupulous businessmen, politicians and extended families to benefit from their corruption, nepotism and favouritism. In the light of these arguments, BEE in South African local government could have done much to equitably re-allocate resources among black communities however various corrupt activities ruined the government efforts.

\section{Methodology}

The paper adopts a qualitative research approach based on an extensive literature study to interrogate the implementation of Black Economic Empowerment Policy in South African municipalities. According to Creswell (2003) qualitative studies are subjective hence they include methods of inquiry such as case study, observations and ethnography. Kumar (2011) holds that, qualitative research is grounded with deductive reasoning which embraces that when the assumptions and theories perfectly fit in study the conclusions and findings will be reliable. As this study relies on secondary analysis of data, various peer reviewed journal articles, policy documentsin BEE, past researches, internet and legislation were used as data collection techniques. The methodology interrogates the effectiveness of BEE as economic empowerment tool to redress socio-economic imbalances of the best. It seeks to questions the restoration of wealth to back South Africans. The data from documentary sources was analysed qualitatively using content analysis where emerging themes and sub-themes were arranged chronologically following the objectives of this paper. 


\section{Results}

The paper has identified various challenges and prospects associated with BEE as an economic empowermentpolicy aimed at redistributing wealth to previously marginalised people in South Africa. These have been discussed below:

The need to curb persistent fraud in BEE systems: BEE procurement systems in South African municipalities have been marred by persistent corruption and fraud. The paper establishes that, corruption in BEE, should be regarded as a moral deterioration which is evidenced by the use of corrupt practices such as bribery or fraud or dishonesty (Craythorne, 2003:328). Most public authorities encourage contractors and consultants to exercise to be ethical when selecting and executing contracts. Mlinga (2005:8) defines corrupt practises as processes of soliciting anything of value, receiving and offering gifts to officials in return for favours. Based on the above assertions, it can be argued that, corruption and fraud are two attributes hindering government plans to redress social-economic inequalities and empower citizens.

The need to curb corruption in BEE tendering systems: The paper acknowledges that, the advent of government tenders has caused what most South Africans call "tenderpreneurship" or acts of gross nepotism, fraud and mismanagement that have crippled the intended purpose of the BEE as an employment creation mechanism in South Africa. The paper recognises that, in the tendering or procurement system, senior or awarding public officials are not paying attention to detail. The BEE system which stipulates the awarding of tenders to deserving black South Africans in diverse economic activities breeds more harm than good to most the citizens. This has been championed by Basheka (2008:380) who observes that, corruption ruined decision making and service delivery in government entities. Although corruption has been rampant in local government procurement systems (Thai, 2008; Tabish et al., 2011:261) claim that, proper exercise of accountability and transparency can enhance municipal activities in the public procurement systems. The paper recognises that, during any phase (planning, financing, tender execution, operation maintenance) in the procurement systems corruption occur (Wensink \& Ecorys, 2013). Public officials often use BEE for personal gain which is a hindrance to black empowerment (Tabish \& Neeraj, 2011:261). The persistent corruption in local government requires officials to increase on public accountability which is a key factor in enhancing good governance in public sector organization. Studies by (Cavil \& Sohail, 2007; Tabish \& Neeraj, 2011: 262; Mpabanga \& Lekorwe, 2007:6) assert that, BEE can be improved in South African local government in event public officials account for their actions which can reduce corruption and mismanagement in public organizations.

The need to improve on accountability and transparency: The paper observes that, after so many years of BEE implementation, local government in South Africa is still grappling with lack of accountability of public officials. The paper recognises that, municipalities do not comply with principles good governance principles inter-arlia transparency, information dissemination, and social accountability as well as monitoring and evaluation of BEE procurement structures. The dearth in accountability culture in local government has led to unending corruption and maladministration which kills the spirit of entrepreneurship and innovation among the historically marginalised groups. The paper acknowledges the view that, if municipalities do exercise social accountability to the public and their peers, black economic empowerment can be a reality in impoverished communities (Swift, 2001:17). In Dowdle (1996:52), public accountability in the implementation of BEE provides a requirement for municipal officials to responsibly account for their actions to the relevant stakeholders. Swift, (2001) argues that, accountability entails the provision of information between two parties where one can justify own actions to the other Ambe \& Badernhorst-Weiss (2012:11004) however, lament the incapability of public officials to effectively account for their actions in BEE which has exacerbated poverty and inequalities in various black marginalised communities nationwide.

The need to improve on registration practises: Many emerging organisations are being constrained by the complexities in the registering of their organisations which is a hindrance to black economic empowerment. Research acknowledges that, BEE is indeed an economic empowerment imperative meant to redress past imbalances, however emerging entrepreneurs due to limited education levels and poor information dissemination find the registration process very infuriating. The Department of Trade \& Industry (2014) attests to the viewpoint that, severalblack companies struggle to comply with the B-BBEE policy, companies 
have employed the services of Verification Agencies (VAs). The prevalence of high level bureaucracy in the verification process, stirs confusion among emerging BEE companies. This calls for alternative strategies to address the issue (DTI, 2014). The paper reasons further that, to cope with the issue of registering companies in line with the BEE requirements, the DTI (2014) observes that the South African National Accreditation System (SANAS) undertaken an initiative to assist in the accreditation and verifications practices. This counter-initiative goes a long way in phasing out certificates issued by non-accredited VAs. All these efforts by this organization were meant to improve efficiency in the BEE systems at the same time promoting local companies to improve on their mandate to create employment (DTI, 2014).

The need to remove excessive decentralization in the procurement system: The procurement system which underpins the BEE systems is marred by excessive decentralization in the governance structures of the country in a way that it spreads to departments, provinces and local municipalities in South Africa. The increased cases of tender fraud and poor service delivery by government at all spheres of government led to critics to interrogate the success of BEE. The lack of proper accountability structures makes one question if public officialsacknowledge the value of taxpayer'smoney (Fawacett, Ellram \& Ogden, 2007:310). The paper argues that centralization of procurement as triggers improved accountability and reduction in costs in local government initiatives (Handfield et al., 2011:162) Centralization in the words of Handfield et al. (2011) offers sound decision making and coordination and it minimises resource wastage. Although centralisation may have its own merits in BEE procurement systems, Handfield et al. (2011:162) argues that decentralisation leads to good responsiveness to local needs, suppliers and decisions based on the available budget.

Improvements in monitoring and evaluation (M\&E) of BEE systems: The paper observes that, the lack of monitoring and evaluation mechanisms in many municipalities in the country has compromised the effective implementation on BEE as a tool for creating employment and redressing socio-economic imbalances. Acevedo et al. (2010) contends that governments need to assess their policy making structures to ensure if they are meeting their objectives or not. The authors maintain that to realise effective governance monitoring and evaluation mechanisms need to be in place to facilitate accountability in public policy formulation. Bogopane (2013) concurs that, poor quality control mechanisms by government departments has resulted in escalating corruption due to poor $M$ \& E structures. The paper affirms further that, lack of compliance by officials promote the culture of corruption in the tendering systems. The laws and regulations as Business Day Report (2011) holds have been by-passed in the procurement systems, leading to the country losing millions of South African rands. Stemele (2009) echoes the same sentiments when he states that mismanagement of funds and corruption is rampant in the upper echelons of government since no-one seems to hold officials accountable. This has harmed BEE to the extent of effectively failing to redistribute resources and wealth the marginalised groups in communities.

BEE and the Emergence of Black Entrepreneurship: The implementation of BEE in South African municipalities as an economic imperative to address the socio-economic inequalities attracted fervent criticism from Moeletsi Mbeki who in 1998-2008 boldly spoke on the need to "formalize BEE through legislation". In his opinion, BEE creates a form of "black entrepreneurship" where small "classes of unproductive but wealthy black crony capitalists" consisting of African National Congress politicians become rich and strong allies of the economic oligarchy (Mbeki, 2009:61). The analyst criticises what he calls "BEE and its subsidiaries-affirmative action and affirmative procurement-have metamorphosed ... they have become both the core black ideology of the black political elite and, simultaneously, the driving material and enrichment agenda which is to be achieved by maximising the process of reparations that accrue to the political elite" (Mbeki, 2009: 61). The criticism levelled against BEE stems from minimal improvement in correcting the injustices of the apartheid as ten years later many of the challenges remain or have become even more acute in terms of poverty, unemployment, housing and basic services, and HIV/AIDS (Hamann, Khagram \&Rohan, 2009: 25). The BEE program in Kovacevic (2007:6) failed to alleviate poverty, regenerate employment and improves the economy of the country. Based on these arguments, this paper questions the ability of BEE to transform the lives of million citizens as enshrined in the policy documents. Evidence on the ground proves otherwise as BEE instead on regenerating employment in local municipalities, it contributes to development of classes where rich black entrepreneurs emerged thereby widening the poverty gap between the rich and poor in communities. 
Curbing Fronting in BEE procurement systems: Evidence from literature study reflected that, fronting is a growing phenomenon which has been embedded in the procurement systems where gross nepotism and fraud are rampant in South African local government. Fronting as Kalula and M'Paradzi (2008) observe entails the deliberate violation, of B-BEE Act and the codes (guidelines on complex structures). Such a gross manipulation of the tendering systems hampers the ability of Small Businesses and other ordinary company owners to benefit from the BEE system. Fronting which has popularly became a fraud mechanism in regarded by the Business Unity South Africaas "an entity, mechanism or structure established to circumvent BEE". The paper observes that fronting is conducted "when black people signed up as fictitious shareholders in essentially white companies and/or inaccurate dis-closure in the submission of tenders" (Barlett, 2010). The empirical literature stresses out that in procurement systems, fronting has been manipulated to side-step BEE (Burger, 2010). As a counter measure to curb fronting, the draft codes issues as per B-BBEE Act in December 1995, were meant to regulate chances of fronting (the SIU Training Manual on Procurement Fraud, 2010:135). The codes give several definitions and formulas that attempt to calculate and reduce the risks of fronting. Although the government of South Africa undertook sound decision to combat fronting in the procurement systems Kalula and M'Paradzi (2008) reason that, fronting in BEE procurement systems has since worked against the government goal of alleviating poverty in communities through local economic development initiatives. Perhaps one might argue that, an organisation or individual that indulges in fronting related activity "stands to be prosecuted, since fronting amounts to fraud and as such it is a criminal offence" Kalula and M'Paradzi (2008). Critics tend to oppose as the unethical acts of fronting and corruption have been rampant in South African municipalities with no or little prosecution enacted on them. Drawing from these assertions therefore; local authorities need to reform on the approach to BEEso that the policy benefits most black people. Rumney (2008) validates the above statements when he declares thatfronting is disguised fraud in accordance with National Prosecuting Authority. The misrepresentation of data, facts by parties claiming compliance by another person amounts to fronting which is an unethical conduct disrupting the success of BEE.

The need to reduce fronting in construction industries and companies: The paper establishes that, fronting is a growing cancer which is ripping the BEE procurement systems apart in local municipalities. The impact of fronting created doubts, lack of trust among citizens on whether public officials can effectively execute their mandate of restoring the black identify by rectifying the socio-economic injustices. Heated debates and questions often arise on whether BEE is indeed a measure for uplifting the living standards of the previously disadvantaged individuals or it a new dimension for enriching the already rich black minority. BEE in South African municipalities has failed to rise to the expected standard due to effects of fronting in the procurement systems. This resulted in many potential small/emerging black company firms encountering relegation out of the system because of corruption (Kalula \& M'Paradzi, 2008). In the Construction industry, fronting and corrupt tendencies have been rife as the procurement systems falls victim to fronting whereby huge contracts are given to BEE companies who later sub-contract them to white owned firms.

Based on the arguments it can be arguedthat BEE targets the previously underprivileged black people, but evidence points to lack of capacity among such groups to embark on the contracts hence they may need their white counterparts to assist for common development. This idea however may attract its own criticism which is a future gap further to be interrogated to see whether the historically marginalised groups in South Africa have the capacity to execute huge contracts without external help. Can the previously marginalised black organisations able regenerate employment without the much-needed skills and expertise? All these questions stand to challenge the implementers of BEE to consider such factors to effectively empower local black owned companies and individuals as part of government plan to reduce poverty inequalities. Critically analysing from a socio-economic standpoint; BEE is facing a host of challenges which inhibit the policy to benefit Historically Disadvantaged (HDIs) Individuals and other marginalised black groupsdue to corruption and inefficiencies in the procurement systems. Probing questions from critics often remain unanswered as to who is to blame for the failure of BEE, government or corrupt individuals? According to the Center for Development and Enterprise (2007:3) BEE was narrowly implemented as it reignites the racially historical divisions and it excludes some segments of the targeted black population. BEE seems to have failed to rise to expectations as poverty and inequalities in communities are escalating despite the government obligation to empower small businesses and emerging black companies. This calls for good ethical conduct of municipal 
officials to exercise good governance as a way of redressing past imbalances and stimulate community livelihoods.

The need to improve on planning, demand \&budget management in BEE procurement system: The success of BEE in redressing the socio-economic imbalances of the past in is hinged on effective municipal coordination and good demand management practises. The paper found out that, demand managementis lacking in local government although, Ambe \& Badenhorst-Weiss (2011) remark that it underpins supply chain management procedures. It enables public officials to undertake efficient and effective procurement decisions. However, the paper observes that, challenges of proper planning and linking demand to the available budget illuminate in South African local government owing to scarcity in skills, and institutional constraints. Evidence of such incapacities in municipalities manifested itself in the cost-effective procurement in the tendering systems where skilled workers are scarce to determine the buying requirements. Lindsay (2015) concurs that, in the implementation of BEE various municipalities lack accurate and realistic strategic plans to direct the path for public officials. The poor planning in government departments sawother departments failing to quantify properly exercise expenditure accountability on the services rendered to the intended beneficiaries. Such capacity constraints in local government can be perceived as a threat to redressing economic injustices by empowering local people in the country. Despite the institutional constraints, there is hope for BEE in South Africa, if municipalities indulge in close monitoring and evaluation of BEE procurement system gaps and weaknesses are located to curb fronting, fraud and corruption associated with the awarding of tenders. As Lyt (2008) observes, this strategy is fundamental in equitably distributing resources effectively and efficiently to improve service delivery in communities.

\section{Conclusion and Recommendations}

The review of secondary evidence reveals that Black Economic Empowerment in South Africa is being constrained by corruption, fraud, mismanagement, poor accountability, lack of monitoring and evaluation, difficulties in registering companies under BEE, lack of demand management and gross incompetence of public officials across municipalities. These obstacles have hindered the capacity of BEE to become an economic imperative aimed at redressing past imbalances. The paper observes that, BEE has led to the emergence of powerful black individuals that manipulate the procurement systems at local government level thereby giving tenders to their friends, peers and relatives. Fraud and fronting have beenconstrainingattributes to have compromised the BEE procurement systems hence increasing the poverty gap in severalmarginalized groups in South African communities. The paper depicts further that; BEE has done little to assist black South Africans since the tendering systems seems to benefit the few minority organizations that have enoughhuman and financial resources to exploit big contracts. Skills deficit coupled with limited funding and poor monitoring of procurement systems cause corruption to persist undetected which cause the rise of unemployment and poverty among the economically active groups in the country.

Despite the many challenges facing local government in South Africa, BEE if well implementedcan still resuscitate the economy of the country by empowering emerging blackentrepreneursand small businesses withfunding and equal opportunity to attain huge tenders that can uplift their standards of living. Based on the above conclusions the study, recommends the government of SouthAfrica, to encourage entrepreneurship andinnovation among black South Africans instead of pinning hopes on BEE initiatives. The government including stakeholders should implement measures that combat corruption and fraud in the procurement systems. Skills development and training programmes need to be strategically implemented to various black communities and emerging entrepreneurs since they are fundamental in generating employment and uplifting standards of living. The BEE policy needs to aligned or implemented together with government's National Development Plan (2011-2030) to empower local communities and redressing previous socioeconomic ills.

\section{References}

Acevedo, G. L., Rivera, K., Lima, L. \& Hwang, H. (2010). Challenges in monitoring and evaluation: an opportunity to institutionalize $\mathrm{M}$ and $\mathrm{E}$ systems. Washington, DC: The International Bank for Reconstruction and Development/the World Bank. 
Ambe, I. M. \& Badenhorst-Weiss, J. A. (2011). An exploration of public sector supply chains with reference to South African situation. Journal of Public Administration, 46(3), 1100-1115.

Ambe, I. M. \& Badenhorst-Weiss, J. A. (2012). Supply Chain Management challenges in South African public service. Journal of Business Management, 6(44), 11003-11014.

Andrews, M. (2008). Is Black Economic Empowerment a South African growth catalyst? (Or could it be...), CID Working Paper No. 170, viewed 16 August 2016, from http://www.hks.harvard.edu/var/ezp_site/storage/fckeditor/file/pdfs/centersprograms/centers/cid/publications/faculty/wp/170.pdf.

Beyers, R. N. \& Koorbanally, N. A. (2010). Computer literacy: Insufficient for digital age literacy learners. Port Elizabeth: Young Engineers and Scientists of Africa, P. 3.

Bezuidenhout, M. M., Joubert, G., Hiemstra, L. A. \& Stuwig, M. C. (2009). Reasons for doctor migration from South Africa. South African Family Practice, 51(3), 211-215.

Basheka, B. C. (2008). Procurement Planning and Accountability of Local Government Procurement Systems in Developing Countries. Journal of Public Procurement, 8(3), 379-406.

Bogopane, L. P. (2013). Evaluation of Black Economic Empowerment (BEE) Policy Implementation in the Ngaka Modiri Molema District, North West Province, South Africa. Journal of Social Sciences, 34(3), 277-288.

Boshoff, W. H. (2012). The strategic implications of black empowerment policy in South Africa: A Case study of Boundary Choice and Client Preferences in a Small Services Firm. Stellenbosch University. SAJEMS NS, 15(2).

Burger, C. Professional Engineer, Ingqandi Consulting. (2010). Statement to author, 23 March. East London. South Africa.

Business Unity South Africa. [s.a]. from: www.busa.org.za/.../Verification\%20 Methodology\%20\%20preferential\%20procurement.ppt- (accessed 19 September 2016).

Brighouse, H. (2002). Egalitarean liberalism and justice in education. USA: Blackwell Publishers.

Burger, R. \& Jafta, R. (2010). Affirmative action in South Africa: An empirical assessment of the impact on labour market outcomes', CRISE Working Paper No. 76, March, viewed 05 August 2016, from http://r4d.dfid.gov.uk/pdf/outputs/ inequality/workingpaper76.pdf.

Business Day. (2011). Irregular state expenditure jumps 62\%. Smart Procurement. Availablefrom:www.smartprocurement.co.za/achives/irregular_state_enpenditure_62.p (Accessed on 30 August 2016).

Cavil, S. \& Sohail, M. (2007). Accountability arrangements to combat Corruption: Literature Review, Water, Engineering and Development Centre. Loughborough University: Loughborough, UK.

Centre for Development and Enterprise (2010). CDE Roundtable - Water: A Looming Crisis? Series Edit: Bernstein, a 2010. Johannesburg: Acumen PublishingSolutions, P.44.

Craythorne, D. L. (2003). Municipal Administration: The Handbook, Cape Town: Juta and Company.

Creswell, J. W. (2003). Research design: Quantitative, Qualitative, and Mixed methods approach (Second Edition). California. Thousand Oaks: Sage Publication.

Dowdle, M. W. (1996). Public Accountability: Designs, Dilemmas and Experiences, Cambridge: Cambridge University Press.

Department of Trade and Industry (DTI). (2006). Construction sector: Broad-based black economic empowerment charter version 6, DTI, Pretoria.

Department of Trade and Industry. (2014). South Africa's economic transformation: A strategy for broadbased black economic empowerment, viewed 29 August 2016, from http://www.dti.gov.za/economic_empowerment/bee-strategy.pdf.

Easterly, W. (2002). The Elusive Quest for Growth: Economists' Adventures and Misadventures in the Tropics. Cambridge: MIT Press.

Fawcett, S. E., Ellram, L. M. \& Ogden, J. A. (2007). Supply chain management - from vision to implementation. Upper Saddle River, Pearson Prentice-Hall.

Gerwitz, S. \& Gribb, A. (2002). Plural conceptions of social justice: implications for policy sociology. Journal of Education Policy, 17, 499-599.

Government of South Africa. (2002). South Africa. Economic Transformation: A Strategy for Broad-Based Black Economic Empowerment. Available at http://www.thedti.gov.za/bee/bee.htm. Accessed 04September 2016. 
Handfield, R. B., Monczka, R. M., Guinipero, L. C. \& Patterson, J. L. (2011). Sourcing and supply chain management. USA, 5th ed. South-Western Cengage Learning.

Jeffery, A. (2016). BEE is flawed and should be scrapped. http://mg.co.za/article/2013-01-18-bee-is-flawedand-should-be-scrapped. Accessed 31 October 2016.

Kalula, E. \& M'Paradzi, A. (2008). Black economic empowerment: can there be trickle down benefits for workers? From: www.research2008.net.ac.za/pdfs/Research 2008.pdf (accessed 27 September 2016).

Kovacevic, N. (2007). Righting wrongs: Affirmative action in South Africa, Harvard International Review, Spring: 6.

Kumar, R. (2011). Research Methodology: A step by step Guide for beginners. $3^{\text {rd }}$ Edition. London: Sage Publications.

Lindsay, D. M. (2015). BEE Informed: A Diagnosis of Black Economic Empowerment and its Role in the Political Economy of South Africa. University of the Witwatersrand. (PhD Dissertation).

Mason, G. \& Watkins, G. (2005). The role of HR in facilitating black economic empowerment, viewed 04 September 2016, from http://www.workinfo.com/free/ downloads/194.htm.

Mathura, A. (2009). The impact of broad-based black economic empowerment on the financial performance of companies listed on the JSE. Gordon Institute of Business Science, University of Pretoria. (Masters Dissertation).

Mbeki, M. (2009). Architects of poverty: why African capitalism needs changing. Johannesburg: Picador Africa.

Mbeki, M. (2016). A manifesto for social change: How to survive South Africa. Johannesburg: Picador Africa.

Mlinga, R. S. (2005). Combating Corruption in Public Procurement, available at www.ppra.go.tz. Accessed 1109-2016.

Papenfus, G. (2015). BEE - a South African dilemma. http://www.biznews.com/thoughtleaders/2015/03/06/bee-south-african-dilemma/. Accessed 31 October 2016.

Rawls, J. (2007). A theory of justice. In: H Lafolette (Ed.): Ethics in Practice. Malden: Blackwell Publishing, 8892.

Rumney, R. (2008). Fronting = BEE? From: www.thoughtleader.co.za/regrumney/ 2008/02/fronting-bee/ (accessed 9 September 2016).

Stemele, B. M. (2009). Assessing good governance in procurement at Lejweleputswa District Municipality. University of Stellenbosch. (Master's Dissertation).

Steger, M. B. (2009). Globalization: A Very Short Introduction. Oxford: Oxford University Press.

South Africa. Broad-Based Black Economic Empowerment Act, 53 of (2003). Pretoria. Government Printers.

South Africa, Draft P3 Input to SALGA Provincial Position Paper on LED - Western Cape March 2010.

South Africa. (1998). Employment Equity Act, 55 of 1998, Government Printers, Pretoria.

South Africa. Constitution of the Republic of South Africa (1996). Pretoria. Government Printers.

Stewart, F. (2001). Horizontal Inequalities: A Neglected Dimension of Development. Paper presented at the Annual Development Lecture

Swift, T. (2001). Trust, reputation and corporate accountability to stakeholders. Business Ethics: A European Review, 10(1), 16-26.

Tabish, S. Z. S. \& Neeraj, J. H. A. (2011). Analysis and evaluation of irregularities in Public Procurement in India. Construction Management and Economics, 29(3), 261-274.

Thai, K. V. (2008). International Handbook of Public Procurement, New York: CRC Press, Taylor and Francis Group. Transparency International Project: Anti-corruption system, available at www. Transparency.org/tools/contracting/construction projects (accessed 15 September 2016).

Wensink, W. \& Jan Maarten de Vet (Ecorys) (2013). Identifying and Reducing Corruption in Public Procurement in the EU: Development of a methodology to estimate the direct costs of corruption and other elements for an EU-evaluation mechanism in the area of anti-corruption. US European Commission. 